\title{
Mutual Fund vs. Life Insurance: Behavioral Analysis of Retail Investors
}

\author{
Dr. Bhagaban Das \\ Senior Reader, P.G. Department of Business Management \\ Fakir Mohan University, Vyasa Vihar-756019, Balasore, Orissa, India
}

Tel: 91-94371-31429 E-mail: bhagaban_fm@yahoo.co.in

Ms. Sangeeta Mohanty

Associate Professor, Academy of Business Administration

Industrial Estate (S1/25), Angaragadia, Balasore - 756001, Orissa, India

E-mail: sangeeta_mohanty@rediffmail.com

\author{
Nikhil Chandra Shil (Corresponding Author) \\ Senior Lecturer \& Assistant Proctor, Department of Business Administration \\ East West University, 43, Mohakhali Commercial Area, Dhaka - 1212, Bangladesh \\ Tel: $88029882308 \quad$ E-mail: nikhilacc@yahoo.com
}

\begin{abstract}
During the post 1990 period, service sector in most of the Asian economies witnessed growth fueled by significant changes in their financial sector. India is now being ranked as one of the fastest growing economy of the world. During last one decade or so, role of Indian insurance and mutual fund industry as a significant financial service in financial market has really been noteworthy. In fact since 1992, a number of research studies have underlined the importance of these two in the Indian capital market environment as important investment vehicles. But the existing 'Behavioral Finance' studies on factors influencing selection of mutual fund and life insurance schemes are very few and very little information is available about investor perceptions, preferences, attitudes and behavior. Yet again, perhaps no efforts are made to analyze and compare the selection behavior of Indian retail investors towards mutual funds and life insurances particularly in post-liberalization period. With this background this paper makes an earnest attempt to study the behavior of the investors in the selection of these two investment vehicles in an Indian perspective by making a comparative study.
\end{abstract}

Keywords: Investor's Behavior, Retail Investors, Mutual Fund, Life Insurance, India

\section{Introduction}

Economic success and sound financial system is intertwined in both literature and practice. Economic reform process of 1991 had a great impact on redefining the financial system of India leading to overall economic development of the country. Today, India's financial system is considered to be sound and stable as compared to many other Asian countries where the financial market is facing many crises. India is now being ranked as one of the fastest growing economy of the world. As the eleventh five-year plan has already in progress, India is targeting a GDP growth rate of around $9 \%$. The savings of the country is now around $29 \%$. Foreign investors are finding Indian market with high potential. India's forex reserve is around $\$ 185$ billion. Inflation is around $7 \%$ which is considered good for a developing economy. Sensex is more than 16000 points in Bombay Stock Exchange. Some experts have opined that the share of the US in world GDP is expected to fall (from 21 per cent to 18 per cent) and that of India to rise (from 6 per cent to 11 per cent) by 2025, and India will emerge as the third pole in the global economy after the US and China. All these favorable things could have not been possible without the sound financial market. The role of Indian mutual fund and insurance industry as significant financial services in financial market has really been noteworthy during last one decade or so. In fact, both of these products have emerged as an important segment of financial market of India, especially in channelizing the savings of millions of individuals into the investment in equity and debt instruments. From retail investors' point of view, keeping large amount of money in bank is not wise as currently bank rate has fallen down below the inflation rate. As in real terms the value of money decreases over a period of time, the only 
options available for them is to invest their money in stock market. However retail investors face a lot of problem in the stock market; viz. limited resources, lack of professional advice, lack of information and so on.

\section{Background of the Study}

The pre-liberalized India had a very poor rate of savings and most of the money earned was spent on consumption rather than accumulation. But in the post-liberalization period, India saw an upsurge in volume of savings as depicted in Table-1.

\section{Insert Table 1 Here}

So, investment companies should continually introduce new types of funds in an effort to attract investor's capital and maximize assets under management (Khorana and Servaes 1999). However investment is increasingly considered as a subject falling under behavioral science rather than finance or economics. It is governed more by trends and group behavior rather than rationality and cold calculations. Investors like consumers are also immensely influenced by fashions and what is "in-thing". Moreover, investors are unique and are a highly heterogeneous group at the retail level. Hence, designing a general product and expecting a good response will be futile (Odean 1999). It is widely believed that Mutual funds (MFs) and Life Insurances (LIs) are designed to target small investors, salaried people and others who are intimidated by the stock market; but on the other hand, like to reap the benefits of stock market investing. In spite of this, the future of mutual fund and life insurance industry in India will be undeniably competitive not only from within the industry but also from other financial products that may provide many of the same economic functions, which is now observed in USA. All this in aggregate, heightens the consumer's confusion in selection of the investment products. Unless the mutual fund and life insurance schemes are tailored to his changing needs, and unless investment companies understand the fund selection/switching behavior of the investors, survival of funds will be difficult in future. Tripathy (1996) in her study observed that with the structural liberalization policies no doubt Indian economy is likely to return to a high grow path in few years, at the same time mutual fund (and life insurance) organizations are needed to upgrade their skills and technology. With this background, a humble attempt is made in this paper to study the factors influencing the fund/scheme selection behavior of Indian retail investors with regards to mutual fund and life insurance products by making a comparative study between these two.

\section{Utility of the Study}

The study will help the individuals to make a wise decision in investing their savings; such as: whom to buy from and where to buy. Further this study will help mutual fund and life insurance companies to understand the profile of Indian retail investors and their behavioral pattern. By knowing this, companies can improve their products and can adopt apposite strategy to tap unexplored market in a better way.

\section{Objective of the study}

In order to examine the issues as raised above, this paper has the following objectives:

a) To understand the retail investors' behavior towards different savings avenues on the basis of their age, gender, education and profession.

b) To identify the features as the retail investors look for in investment products

c) To identify the scheme preference of investors

d) To identify the factors those influence the investor's fund/scheme selection

e) To identify the source of information that influences the fund/scheme selection decision.

\section{Limitations of the Study}

Like most of the other social researches, the study suffers from the following limitations that should be considered carefully at the time of generalizing the findings of the study:

a) Sample size is limited to 100 educated investors in metro cities only. The sample size may not adequately represent the national market.

b) This study has not been conducted over an extended period of time having both market ups and downs. The market state has a significant influence on the buying patterns and preferences of investors.

With these limitations, the next section briefly describes the conceptual framework of mutual funds and life insurance as well as gives an overview Indian mutual funds and life insurance industry. Then reviews from the available literature on the subject are presented followed by a discussion on the methodology adopted for the study. Later on, a detail analysis is presented on the selection behavior of retail investors towards mutual funds and life insurance products. Finally, the paper is ended with the findings of the study and some concluding remarks.

\section{Conceptualization of Mutual Fund and Life Insurance}

A Mutual Fund is a trust that pools the savings of a number of investors who share a common financial goal. The money thus collected is then invested in capital market instruments such as shares, debentures and other securities. The income earned through these investments and the capital appreciations realized are shared by its unit holders in 
proportion to the number of units owned by them. Thus a Mutual Fund is the most suitable investment for the investment-illiterate people as it offers an opportunity to invest in a diversified, professionally managed basket of securities at a relatively low cost. The flow chart below (Figure 1) describes broadly the working of a mutual fund:

Insert Figure 1 here

Life Insurance or Life Assurance, on the other hand, is a contract between the policy owner and the insurer where the insurer agrees to pay a sum of money upon the occurrence of the insured. Insurance should be considered a key component of economic development and the best mechanism to take care of multidimensional risks in modern economies (Lindley 2007).

\section{Indian Mutual Funds and Insurance Industry - An Overview}

The origin of Mutual Fund Industry in India is with the introduction of the concept of mutual fund by Unit Trust of India (UTI) in the year 1963. Though the growth was slow initially, it has been accelerated from the year 1987 when non-UTI players entered the industry. With the boom of June 1990 and then again 1991 due to the implementation of new economic policies leading to structural change of securities pricing in stock market, the performance of the mutual fund industry is encouraging. Because, individual investors have been emphasized in India in contrast to advanced countries where mutual funds depend largely on institutional investors. In general, it appears that the mutual fund in India have given a good account of itself so far. With the entry of private sector funds in 1993, a new era started in the Indian mutual fund industry, giving the Indian investors a wider choice of fund families. The industry now functions under the SEBI (Mutual Fund) Regulations 1996. The number of mutual fund houses goes on increasing with many foreign mutual funds setting up funds in India and also the industry has witnessed several mergers and acquisitions. As at the end of January 2005, there were 33 mutual funds with total assets of Rs.121805 cores. The industry has grown in size and manages total assets of more than $\$ 30351$ million. Of the various sectors, the private sector accounts for nearly $91 \%$ of the resources mobilized showing their overwhelming dominance in the market. Individuals constitute $98.04 \%$ of the total number of investors and contribute US $\$ 12062$ million, which is $55.16 \%$ of the net assets under management.

The Indian Life Insurance Industry is driven by factors like incidences of natural calamities at regular intervals, shifting consumer behavior, rising insurance contribution to GDP and changing socio-economic demography. The growth of the life insurance products has been further boosted by the entry of private players following the deregulation of the industry in 2000. They have contributed a lot to the industry by introducing new distribution channels (such as banc assurance) and strategies to the industry. The rising demand for retirement provision in the ageing population along with efforts of governments to move from public to private pension schemes has also led to rapid growth. Filliped by the above factors, it is reported that the life insurance market to swell at a CAGR of over 200\% during 2006-2009. The dynamic growth of insurance buying is partly affected by the (changing) income elasticity of insurance demand. It has been shown that insurance penetration and per capita income have a strong non-linear relationship (Enz 2000). Based on this relation and other considerations, it can be postulated that by 2014 the penetration of life insurance in India will increase to $4.4 \%$ (Table 2).

Insert Table 2 Here

Yet, more than three-fourth of India's insurable population has no life insurance coverage. Considering that only about 65 million out of 250 million people are covered by life insurance, the potential is quite evident.

\section{Review of Literature}

Since 1992, a number of articles and brief essays have been published in financial dailies, periodicals, professional and research journals, explaining the basic concept of Mutual Funds and life insurances and behavior of investors on them. They underline the importance of mutual funds and life insurances in the Indian capital market environment. They touch upon varied aspects like regulation of mutual funds and life insurances, investor expectations, investor safety, trend in growth and some other critical views on the performance and functioning of mutual funds/life insurance schemes. For cases in point, Ippolito (1992) says that fund/scheme selection by investors is based on past performance of the funds and money flows into winning funds more rapidly than they flow out of losing funds. Gupta (1994) made a household investor survey with the objective to provide data on the investor preferences on MFs and other financial assets. The findings of the study were more appropriate, at that time, to the policy makers of mutual funds to design the financial products for the future. Kulshreshta (1994) offers certain guidelines to the investors in selecting the mutual fund schemes. Shankar (1996) points out that the Indian investors do view Mutual Funds as commodity products and AMCs, to capture the market should follow the consumer product distribution model. Jambodekar (1996) conducted a study to assess the awareness of MFs among investors, to identify the information sources influencing the buying decision and the factors influencing the choice of a particular fund. The study reveals among other things that Income Schemes and Open Ended Schemes are more preferred than Growth Schemes and Close Ended Schemes during the then prevalent market conditions. Sikidar and Singh (1996) carried out a survey with an objective to understand the behavioral aspects of the investors of the North Eastern region towards mutual funds investment portfolio. The survey 
revealed that the salaried and self-employed formed the major investors in mutual fund primarily due to tax concessions. Lynch and Musto (2003) were of opinion that this decade will belong to mutual funds because the ordinary investor does not have the time, experience and patience to take independent investment decisions on his own. Goetzman and Peles (1997) established that there is evidence of investor psychology affecting fund/scheme selection and switching. Sundar (1998) conducted a survey to get an insight into the mutual fund operations of private institutions with special reference to Kothari Pioneer. The survey revealed that agents play a vital role in spreading the Mutual Fund culture; open-end schemes were much preferred then age and income are the two important determinants in the selection of the fund/scheme; brand image and return are the prime considerations while investing in any Mutual Fund. Khorana and Servaes (1999) had experimented that the decision to introduce a new type of fund is affected by a number of variables, including investor demand for the fund's attributes. Chakarabarti and Rungta (2000) stressed the importance of brand effect in determining the competitive position of the AMCs. Their study reveals that brand image factor, though cannot be easily captured by computable performance measures, influences the investor's perception and hence his fund/scheme selection. Shanmugham (2000) conducted a survey of 201 individual investors to study the information sourcing by investors, their perceptions of various investment strategy dimensions and the factors motivating share investment decisions, and reports that among the various factors, psychological and sociological factors dominate the economic factors in investment decisions. In his study “Are Retail Investors Better off Today?" Black (2004) observed that in recent years, investors' attitudes towards the securities industry plummeted, in reaction to both the conflicted research and the mutual fund scandals. He concluded that the most optimistic assessment is that the SEC has plenty of unfinished business to attend to. Keli (2005) is of opinion that Past performance and Fund's Investment Strategy continued to be the top two drivers in the selection of a new fund manager. Rajeswari and Moorthy (2005) observed that investors demand inter-temporal wealth shifting as they progress through the life cycle. Omar and Frimpong (2006) stressed the importance of life insurance and regarded it as a saving medium, financial investment, or a way of dealing with risks. Alinvi \& Babri (2007) are of view that customers' preferences change on a constant basis, and organizations adjust in order to meet these changes to remain competitive and profitable.

Studies on life insurance use dates back to Heubner (1942) who postulated that human life value has certain qualitative aspects that gives rise to its economic value. Hakansson's (1969) study indicates that demand for life insurance varies inversely with the wealth of the individuals. Lewis (1989) found out that the number of dependents has an influence on the demand for life insurance. Headen and Lee (1974) studied the effects of financial market behavior and consumer expectations on purchase of ordinary life insurance and concluded that life insurance demand is inelastic and positively affected by change in consumer sentiments; interest rates playing a role in the short run as well as in the long run. The study by Truett et al. (1990) discussed the growth pattern of life insurance consumption in Mexico and United States in a comparative framework, during the period 1964 to 1984. They concluded the existence of higher income inelasticity of demand for life insurance in Mexico with low income levels. Age, education and income were significant factors affecting demand for life insurance in both countries. The study by Browne et al. (1993) based on 45 countries for two separate time periods (1980 and 1987) concluded that income and social security expenditures are significant determinants of insurance demand, however, inflation has a negative correlation. Black and Skipper (2000), is of opinion that life insurance becomes the mechanism to ensure a continuous stream of income to the beneficiaries. The two main services provided by life insurance: income replacement for premature death and long-term savings instruments, are the starting point for Beck et al. (2003). The studies by Ward et al. (2003) and Beck et al. (2003) evolves around the issue of finding the cause behind variations in life insurance consumption across countries. After almost three decades of empirical work in this direction, they are of the opinion that "it is still hard to explain the anomalous behavior of Asian countries with higher savings rate, large and growing population, relatively low provision for pensions or other security and a sound capital market but comparatively low per-capita consumption of insurance. Except Japan, most of the Asian countries have low density and penetration figures". Raman and Gayatri (2004) have observed the customers' awareness towards insurance companies. They found that $53 \%$ of the respondents belong to the age group below $30,24 \%$ to the age group 31-40, $2 \%$ belong to the age group of $41-50$ and the rest to the age group of 'above 50'. Further they also observed that a large percentage of the insured respondents (32\%) are professionals, and $56 \%$ of the respondents are married. They have also found that $52 \%$ of the respondents have taken a policy to cover life risk, $44 \%$ of them to get tax advantage and the reaming to invest for growth of capital. Zietz (2003) and Hussels et al. (2005) has reviewed the efforts of researchers to explain consumer behavior concerning the purchase of life insurance for almost 50 years. The review of earlier studies concludes that bulk of the empirical studies undertaken finds a positive association between increase in savings behavior, financial services industry and demand for life insurance. There are two detailed studies on the determinants of life insurance demand, one taking into consideration only the Asian countries and the other based on 68 economies. Chowdhury, Rahman and Afza (2007) have found in a survey that a good number of people are choosing insurance companies with a view to earn higher return on deposited money. Rajkumari (2007) in her study undertaken to identify the customers' attitude towards purchase of insurance products concludes that there is a low level of awareness about insurance products among customers in India. Fatima Alinvi (2008) suggests that customers change their preferences according to their life circumstances and while certain 
preferences are well-defined others can be inconsistent. In an increasingly competitive environment, where insurance companies fight for the same customers, having a customer-oriented culture is extremely important not only to retain customers but also to acquire new ones.

From the above discussion it can be inferred that Mutual Fund and Life Insurance as an investment vehicles are capturing the attention of various segments of the society, like academicians, entrepreneurs, financial intermediaries, investors and regulators for varied reasons. But the existing studies on factors influencing selection of Mutual Fund and Life Insurance schemes are very few and very little information is available about investors' perceptions, preferences, attitudes and behavior. Yet again all efforts in this direction are fragmented. Thus this paper makes an earnest attempt to study the behavior of the retail investors, a class who got less attention in research, in their selection of the Mutual Funds and Life Insurances products in an Indian perspective.

\section{Data Collection and Methodology}

Due to constraints of resource and time along with preliminary nature of this investigation, only 100 interviews were made from two metros of Orissa viz.; Cuttack and Bhubaneswar. Simple random sampling was followed to select the sample. To obtain a probability sample, considerable effort was devoted to selecting the appropriate sample plan. The unit of observation and analysis of this survey is an individual, who is at present a retail investor. Our definition of present retail investor is "An individual who has currently (i.e., as on August, September or October 2007) invested in any MF/Life Insurance scheme”. The population was defined as residents of Cuttack and Bhubaneswar cities who have Mutual Fund/Life Insurance policy in any company.

A preliminary version of the questionnaire was developed in English on the basis of insights from in-depth qualitative interviews with experts, mutual fund investors/insurance policyholders. The instrument was then translated into local language (Oriya) and then re-translated until a panel fluent in English and Oriya agreed that the two versions were reasonably comparable. Besides, personal observation was done where necessarily applicable. A pilot survey was conducted in the cities and the questionnaire was improved in that light. Interviewers were given a letter of introduction from university so that respondents would see that the study was authentic. A telephone number was provided too, in case respondents wanted to verify the identity of the investigators or clarify questions of concern. Several difficulties were encountered during data collection. Few refused to grant interview because, being unfamiliar with such studies, they were suspicious of the interviewers or purpose of the study.

\section{Tools and Techniques used}

Tables, bar diagram and structures are used in explanations to bring out the point more clearly. Tabulation of the primary data was done. On the basis of these tables, trends came out more visibly. Other statistical techniques those are used in the present study include:

a) Percentage Method: to show the trend of the variable.

b) Chi-square: to test the independence of the attributes.

c) Two-way ANOVA: to test the equality of the variances between two sets of variables.

d) Rank correlation: to find the relationship between two variables.

e) Z-test: to test the equality of two-population proportion.

f) $t$-test: to test the significance of the results of rank correlation.

g) Kendall's concordance test: to test the significance of agreement in ranking.

\section{Hypotheses}

(1) For analyzing the pattern of investment on the basis of Age, Education and Profession the following hypotheses are taken into consideration:

$\mathrm{H}_{0}$ : There is no significant difference in investments avenues among the investors on the basis of their age, qualification and profession.

$\mathrm{H}_{1}$ : There exists a significant difference in investments avenues among the investors on the basis of their age, qualification and profession.

$\mathrm{H}_{1 \mathrm{a}}$ : There is a difference in the investment pattern amongst the investors of different age groups.

$\mathrm{H}_{1 b}$ : There is a difference in the investment pattern amongst the investors on the basis of their level of education.

$\mathrm{H}_{1 \mathrm{c}}$ : Moreover, there is a difference in investment pattern among the investors based on their professions.

(2) For gender-wise analysis, the interest lies in taking the gender wise preference to the different investment pattern by using large sample Z-test, the hypothesis under consideration is:

$\mathrm{H}_{2}$ : Males invest more as compared to females. 
(3) For objective-wise analysis, the basic interest is to test the independence of two attributes (objective and investment pattern) by using $\chi^{2}$ test, the hypothesis of interest is:

$\mathrm{H}_{3}$ : The investment pattern is independent of the objective of investment.

(4) For company-wise analysis of life insurances, the significance of agreement amongst the respondents ranking can be tested by Kendall's concordance test. The hypothesis under consideration is:

$\mathrm{H}_{4}$ : There is a disagreement in ranking.

(5) For company-wise analysis of the mutual funds, the significance of correlation coefficient in between the ranks is required to be tested by using the hypothesis:

$\mathrm{H}_{5}$ : Two variables are not associated. $(\mathrm{r}=0)$.

\section{Analysis and Interpretations}

\subsection{Age-wise Analysis}

Investors in any industry comprise people from different age groups and their investment pattern also differs significantly on the basis of age groups. For case in point, Alinvi \& Maira Babri (2007) is of view that young customers become strategic group for companies within the financial industry. Therefore, understanding young customers' perspectives is important for financial companies to be able to provide the services they demand. The sample in our study constitutes investors from the age groups of: Under 25, 26-36, 37-47, 48-58 and above 58 and it corroborates to findings of the above study, i.e. majority of our respondents are young customers and they belong to the age group of 26-36. Again, as we are interested to know the difference in the investment pattern across different age groups, a two-way ANOVA is worked out for each of the following hypotheses:

$\mathrm{H}_{01}$ : There is no significant difference in the investment pattern amongst the investors of different age groups.

$\mathrm{H}_{02}$ : Different investment patterns do not differ much among themselves.

\begin{tabular}{|l|c|r|r|r|}
\hline \multicolumn{5}{|c|}{ ANOVA Table-I } \\
\hline Sources of Variation & d. f. & \multicolumn{1}{c|}{$\begin{array}{c}\text { Sum of } \\
\text { squares }\end{array}$} & $\begin{array}{c}\text { Mean Sum of } \\
\text { squares }\end{array}$ & \multicolumn{1}{c|}{$\mathrm{F}$} \\
\hline Row (Investment Pattern) & 5 & 83.37 & 16.674 & $\mathrm{~F}_{1}=3.3481$ \\
\hline Column (Age) & 4 & 141.67 & 35.41 & $\mathrm{~F}_{2}=7.11$ \\
\hline Error & 20 & 99.63 & 4.98 & \\
\hline Total & 29 & & & \\
\hline
\end{tabular}

$\mathrm{F}_{0.05}(5,20)=2.71<$ Cal. $\mathrm{F}_{1}$ (Investment Pattern)

$\mathrm{F}_{0.05}(4,20)=2.87<$ Cal. $\mathrm{F}_{2}$ (Age)

------ $\mathrm{H}_{02}$ is rejected

As both $\mathrm{H}_{01}$ and $\mathrm{H}_{02}$ are rejected, it is inferred that the investors have significant difference in the pattern of investment with respect to their age. Further to find out which of the row-means differ significantly, the Critical Difference (the least difference between any two means to be significant) was calculated and the results are as follows:

Critical Difference, $C D=t_{0.05}$ for error d.f. $\sqrt{M S E\left[\frac{2}{r}\right]}=6.58$, where $\mathrm{r}=$ no. of replications

\begin{tabular}{|c|l|r|}
\hline Category & Investment Pattern & Row mean \\
\hline A & Bank FD & 4 \\
\hline B & Shares & 1.8 \\
\hline C & Mutual Funds & 3.6 \\
\hline D & Life Insurance Policies & 6.2 \\
\hline E & Govt. Saving Schemes & 3.6 \\
\hline F & Others & 0.8 \\
\hline
\end{tabular}

After determining the critical differences and comparing the same with each other, it is observed that there is insignificant difference among the treatments $\mathrm{A}, \mathrm{B}, \mathrm{C}, \mathrm{D}$, and $\mathrm{E}$ (row wise). Again,

Critical Difference, $C D=t_{0.05 \text { for error d.f. }} \sqrt{M S E\left[\frac{2}{r}\right]}=6$, where $\mathrm{r}=$ no. of replications 


\begin{tabular}{|c|l|c|}
\hline Category & Age & Column Mean \\
\hline $\mathrm{A}_{1}$ & Under 25 & 1 \\
\hline $\mathrm{B}_{1}$ & $26-36$ & 6 \\
\hline $\mathrm{C}_{1}$ & $37-47$ & 4.67 \\
\hline $\mathrm{D}_{1}$ & $48-58$ & 4.33 \\
\hline $\mathrm{E}_{1}$ & 58 and above & 0.66 \\
\hline
\end{tabular}

Finding out the critical differences and comparing these with each other, we find insignificant difference among the treatments $\mathrm{A}_{1}, \mathrm{~B}_{1}, \mathrm{C}_{1}, \mathrm{D}_{1}$, and $\mathrm{E}_{1}$ (column wise).

(1) $\mathrm{As} \mathrm{H}_{01}, \mathrm{H}_{02}$ are rejected at $5 \%$ level of significance, we can conclude that different investment avenues do not provide the same level of satisfaction and also the investors differ in the choice of their investment avenues according to their age.

(2) But insignificant difference (row-wise and column-wise) implies that although the investment avenues are significantly different in providing satisfaction, the investors do not have considerable variation in their preferences on the basis of their age.

\subsection{Educational Qualification-wise Analysis}

Our sample consists of the investors, which spread on a cross-section of the different educationally qualified groups starting from tertiary to professional degrees. Majority of the respondents are graduates. The fundamental objective of this analysis is to find out whether the investment pattern varies with respect to the level of education or not. To authenticate this, a two-way ANOVA is worked out for testing each of the following hypotheses:

$\mathrm{H}_{01}$ : There is no major deviation in the investment patterns amongst the investors on the basis of their level of education.

$\mathrm{H}_{02}$ : Different investment patterns do not differ much among themselves.

\begin{tabular}{|l|c|r|r|r|}
\hline \multicolumn{5}{|c|}{ ANOVA Table -II } \\
\hline Sources of Variation & d. f. & Sum of Squares & $\begin{array}{c}\text { Mean Sum of } \\
\text { Squares }\end{array}$ & \multicolumn{1}{c|}{ F } \\
\hline Row (Investment Pattern) & 5 & 85.33 & 17.066 & $\mathrm{~F}_{1}=2.39$ \\
\hline Column (Education level) & 3 & 338.996 & 112.99 & $\mathrm{~F}_{2}=15.84$ \\
\hline Error & 15 & 107.004 & 7.13 & \\
\hline Total & 23 & & & \\
\hline
\end{tabular}

$\mathrm{F}_{0.05}(5,15)=2.90>$ Cal. $\mathrm{F}_{1}$ (Investment Pattern) $\quad$------ $\mathrm{H}_{01}$ is accepted

$\mathrm{F}_{0.05}(3,15)=3.29<$ Cal. $\mathrm{F}_{2}$ (Education level) ------- $\mathrm{H}_{02}$ is rejected

As $\mathrm{H}_{01}$ is accepted and $\mathrm{H}_{02}$ is rejected at $5 \%$ level of significance, at this point it can be concluded that although the different investment patterns give more or less the equal level of satisfaction, there are still some variation among the investors basing upon their level of education. Consequently we are interested to know which pair of education-level differs most among them. To be more likely with the results, we find out the Critical Difference (CD) and the result is as follows:

Critical Difference, $C D=t_{0.05}$ for error d.f. $\sqrt{M S E\left[\frac{2}{r}\right]}=8.71$, where $\mathrm{r}=$ no. of replications

\begin{tabular}{|c|l|c|}
\hline Category & Education level & Column mean \\
\hline A & Matriculates & 0.5 \\
\hline B & Intermediates & 0.5 \\
\hline C & Graduates \& Post Graduates & 9.0 \\
\hline D & Professional Degree Holders & 6.66 \\
\hline
\end{tabular}

By judging the critical difference and comparing these with each other, we find insignificant variation among the treatments of A, B, D (column wise), whereas the treatment C (Graduates \& Post Graduates) differs most significantly 
from others. The highest mean score for the graduate \& postgraduate investors as shown above also corroborates our earlier observation in this context.

\subsection{Profession-wise Analysis}

By and large, investors from different professions invest for dissimilar purposes. The pattern of investment might have significant difference so far as their profession is concerned. For this purpose, a two-way ANOVA is furthermore worked out on the basis of following hypotheses:

$\mathrm{H}_{01}$ : There is no difference in the investment pattern among the investors from different professions.

$\mathrm{H}_{02}$ : Different pattern of investment do not differ much.

\begin{tabular}{|l|c|c|c|c|}
\hline \multicolumn{7}{|c|}{ ANOVA Table -III } \\
\hline Sources of variation & d. f. & $\begin{array}{c}\text { Sum of } \\
\text { squares }\end{array}$ & $\begin{array}{c}\text { Mean Sum of } \\
\text { squares }\end{array}$ & F \\
\hline Row (Investment Pattern) & 5 & 83 & 16.6 & $\mathrm{~F}_{1}=3.64$ \\
\hline Column (Profession) & 4 & 183 & 45.75 & $\mathrm{~F}_{2}=10.05$ \\
\hline Error & 20 & 91 & 4.55 & \\
\hline Total & 29 & 357 & & \\
\hline
\end{tabular}

$\mathrm{F}_{0.05}(5,20)=2.71<$ Cal. $\mathrm{F}_{1}$ (Investment Pattern) ------- $\mathrm{H}_{01}$ is rejected

$\mathrm{F}_{0.05}(4,20)=2.87<\mathrm{Cal} . \mathrm{F}_{2}$ (Profession) ------ $\mathrm{H}_{02}$ is rejected

Thus it can be believed that, investors have extensive differences with respect to their professions and the different patterns of investment vary widely among themselves as well. Moreover, we have calculated the Critical Difference (CD) to find out which of the row-means differ significantly.

Critical Difference, $C D=t_{0.05 \text { for error d.f. }} \sqrt{\operatorname{MSE}\left[\frac{2}{r}\right]}=6$, where $\mathrm{r}=$ no. of replications

\begin{tabular}{|c|l|c|}
\hline Category & Investment Pattern & Row mean \\
\hline A & Bank FD & 4.4 \\
\hline B & Shares & 2.0 \\
\hline C & Mutual Funds & 3.6 \\
\hline D & Life Insurance Policies & 5.8 \\
\hline E & Govt. Saving Schemes & 3.6 \\
\hline F & Others & 0.6 \\
\hline
\end{tabular}

Insignificant difference among the treatments A, B, C, D, E (row wise) was observed after calculating the critical differences and comparing these with each other. Again,

Critical Difference $C D=t_{0.05 \text { for error d.f. } \sqrt{M S E\left[\frac{2}{r}\right]}}=5.467$, where $\mathrm{r}=$ no. of replications

\begin{tabular}{|c|l|c|}
\hline Category & Occupation & Column mean \\
\hline $\mathrm{A}_{1}$ & Govt. Servants & 7.16 \\
\hline $\mathrm{B}_{1}$ & Businessmen & 4.5 \\
\hline $\mathrm{C}_{1}$ & Private Servant & 3.66 \\
\hline $\mathrm{D}_{1}$ & Students & 0.6 \\
\hline $\mathrm{E}_{1}$ & Others & 0.6 \\
\hline
\end{tabular}


Again, we find an insignificant difference among the treatments of $\mathrm{B} 1, \mathrm{C}_{1}, \mathrm{D}_{1}, \mathrm{E}_{1}$ (column wise) and the treatment $\mathrm{A}_{1}$ (Govt. servants) differs most from $\mathrm{D}_{1}$ (Students) and $\mathrm{E}_{1}$ (Others) after determining the critical differences and comparing these with each other. So it can be concluded that, on an average; the government servants are investing to the maximum extent, whereas the students and other professional groups are investing the least in mutual funds and insurance policies.

\subsection{Gender-Wise Analysis}

Though men and women are two sides of the same coin, women still have the main responsibility for meeting household needs and are therefore a major force in determining consumption trends. As such, women have an essential role to play in the development of economically sound consumption and production patterns.

For this purpose, we have performed the large sample test $(Z)$ in order to invalidate the proposition that men invest more than women. For the purpose, the following hypotheses are taken into consideration:

Null hypothesis: $H_{0}: P_{1}=P_{2}$

Alternative hypothesis: $H_{1}: P_{1}>P_{2}$ (right-tailed test)

Test statistic:

$$
Z=\frac{P_{1}-P_{2}}{\sqrt{\left\{P Q\left(\frac{1}{n_{1}}+\frac{1}{n_{2}}\right)\right\}}}
$$

Where, $\mathrm{P}_{1}=$ Population proportion of males

$$
\begin{aligned}
& \mathrm{P}_{2}=\text { Population proportion of females } \\
& \mathrm{n}_{1}=\text { Total no. of males in the sample }=70 \\
& \mathrm{n}_{2}=\text { total no. of females in the sample }=30
\end{aligned}
$$

Level of significance is $5 \%=0.05$

$$
P=\frac{n_{1} p_{1}+n_{2} p_{2}}{n_{1}+n_{2}} \text { and } Q=1-P
$$

$\mathrm{P}_{1}=$ Sample proportion $\quad$ of male $=(50 / 70)=0.714$

$\mathrm{P}_{2}=$ Sample proportion $\quad$ of female $=(10 / 30)=0.30$

Thus, $\mathrm{P}=0.60$ and $\mathrm{Q}=0.40$

$$
\begin{gathered}
Z=\frac{0.60-0.30}{\sqrt{\left\{0.60 \times 0.40\left(\frac{1}{70}+\frac{1}{30}\right)\right\}}}=2.80 \\
Z_{\text {tab }}=1.96 \text { at } 5 \% \text { level of significance. }
\end{gathered}
$$

As $\mathrm{Z}_{\text {cal }}>\mathrm{Z}_{\mathrm{tab}}, \mathrm{H}_{0}$ is rejected and $\mathrm{H}_{1}$ is accepted, accordingly it can be established that men are dominating in Indian mutual funds and life insurance industry as compared to women.

\subsection{Objective-wise Analysis}

Different investors enter in the investment industry with different objectives in mind. Some investors could have multiple intentions. Jambodekar (1996) found that investors look for safety of principal, liquidity, capital appreciation and many others in the order of importance. However for the sake of convenience, we have restricted our study to the objectives of safety of principal, capital growth, regular income, tax saving, and retirement plan. This analysis automatically led to the testing of following hypothesis:

$\mathrm{H}_{0}$ : The pattern of investment is independent on the objective of investing

$\mathrm{H}_{1}$ : The pattern of investment is dependent on the objective of investing

The validity of testing above was achieved by applying $\chi^{2}$ (chi-square) test.

$$
\chi^{2}=\sum\left[\frac{(O-E)^{2}}{E}\right]=26.645>24.996\left(\text { Tab. Val of } \chi^{2}(0.05) \text { at } 15 \text { d. f. }\right)
$$

Thus, $\mathrm{H}_{0}$ is rejected and $\mathrm{H}_{1}$ is accepted concluding that the pattern of investment is dependent upon the objective of investing. Majority of the investors (35\%) are investing for capital growth, followed by the tax saving objective (28\%) and regular income $20 \%$. On the other hand, only $17 \%$ of them are investing for the retirement plan. 
Normally, the investment pattern depends on individual income of the investor. To analyze this we have collected data on a 3-point scale and obtained the following results.

Maximum investors (30\%) like to invest in life insurance policies followed by mutual fund (20\%) and government saving schemes $(18 \%)$.

Majority of the respondents (58\%) belongs to the income group (2.5-5lakhs) followed by (5-7.5 lakhs), and one interesting observation we found, i.e. $75 \%$ respondents of the income group (2.5-5lakhs) prefer to invest in the life insurance policies.

\section{Mutual Fund vs. Life Insurance}

The above results obviously lead to the fact that life insurance policies and mutual funds are two most preferred avenues for retail investors. For this reason we are enticed for a comparative study on Life Insurance Policies and Mutual Funds.

\subsection{Company-wise analysis of Life insurance}

Of all the top life insurance companies in India, we have included only LIC, ICICI, SBI and HDFC for this study. The pilot survey conducted on a small group of sample investors is the basis of choosing these companies. Out of 30 respondents approached, 20 of them gave the favorable responses to above companies. The data had been collected using ranking method and the companies were ranked on the basis of the responses given by the respondents.

\begin{tabular}{|l|c|c|c|c|c|}
\hline Particulars & LIC & HDFC & ICICI & SBI & Total \\
\hline Rank sum (SR) & 40 & 59 & 40 & 61 & 200 \\
\hline$(\mathrm{SR})^{2}$ & 1600 & 3481 & 1600 & 3721 & 10402 \\
\hline
\end{tabular}

By Kendalls' Coefficient of Concordance, we could able to estimate the relationship and test whether the different respondents are in agreement or not. The results are as follows:

$\mathrm{H}_{0}$ : The respondents have disagreement in ranking.

$\mathrm{H}_{1}$ : The respondents have agreement in ranking.

Test statistic

Kendall's coefficient of concordance is given by the following rule

$W=\frac{S}{1 / 12 k^{2}\left(n^{3}-n\right)}, \mathrm{n}=4$ (no. of companies ranked), $\mathrm{k}=20$ (no. of respondents).

Where,

$$
\begin{aligned}
& S=\sum(S R)^{2}-n(\overline{S R})^{2}=10402-4 * 2500=402 \\
& W=\frac{S}{1 / 12 k^{2}\left(n^{3}-n\right)}=402 / 2000=0.201 \\
& \overline{S R}=\frac{(n+1) k}{2}=50, \text { if we had complete disagreement, every applicant would have a rank sum of } 50 .
\end{aligned}
$$

Kendall's Coefficient of Concordance approximately follows $\chi^{2}=k(n-1) W=20 * 3 * 0.201=12.06$ with (n-1) d. f.

$\chi^{2}($ cal. $)=12.06>\chi^{2}$ (tab with 3 d.f. and at $5 \%$ level of significance $)=7.81$

As $\mathrm{H}_{0}$ is rejected, we can conclude that respondents have the nearest approach to the same ranking.

From the survey it is found that a large group of Indian retail investors (49\%) ranked LIC as number one, ICICI (29\%) as number two and HDFC (15\%) as number three and SBI (7\%) as number four.

\subsection{Sector-wise Analysis of Life Insurance Companies}

\begin{tabular}{|c|c|}
\hline \multicolumn{2}{|c|}{ Sector wise analysis of Life insurance Companies } \\
\hline Sector & Investors' Preference (\%) \\
\hline Public & 68 \\
\hline Private & 32 \\
\hline Total & 100 \\
\hline
\end{tabular}

When many investors are interested to invest in life insurance policies, they might have preference for a particular 
sector, i.e. private or public. Many are of view that the private sector brings superior changes and more investor-friendly than the public sector. But in case of life insurance we got the reverse scenario as shown in the following table.

Majority $(68 \%)$ of the investors are of the opinion that the public sector is better than the private sector.

\subsection{Company-Wise analysis of Mutual Funds}

The mutual fund route of investment has unique characteristics that make it significant to the retail investors. The growing popularity of funds is not because of the booming stock market, but due to the fact that it offers the best in terms of variety, liquidity, tax efficiency, flexibility, diversification and professional money management. To know the preferences of the investors towards leading Mutual Fund companies, the data had been collected over three characteristics, Brand image, Past Performance, and Volume of the business using ranking method. The following table is constructed on the basis of the majority of the decision furnished by the respondents.

\begin{tabular}{|l|c|c|c|}
\hline Company & Brand Image (x) & Past Performances (y) & Volume of Business (z) \\
\hline ICICI & 1 & 2 & 2 \\
\hline Kotak & 4 & 3 & 4 \\
\hline UTI & 2 & 1 & 3 \\
\hline Reliance & 3 & 4 & 1 \\
\hline Birla & 5 & 5 & 5 \\
\hline
\end{tabular}

In order to know the relation in between $\mathrm{x}, \mathrm{y}, \mathrm{z}$, we have worked out Spearman's Correlation coefficient (Rank correlation coefficient) pair wise.

$\mathrm{R}_{\mathrm{xy}}=0.975, \mathrm{Rxz}=0.7, \mathrm{Ryz}=0.883$

$\mathrm{R}_{\mathrm{xy}}=$ The correlation coefficient between the brand image and the past performance (0.975) is maximum; it shows a very high degree of positive correlation in between the said variables.

Then the significance of the coefficient of rank correlation was tested by using small sample (' $t$ ') test.

$\mathrm{H}_{0}$ : Two variables are not associated, i.e., $\mathrm{r}=0$

$\mathrm{H}_{1}$ : Variables are associated

Test statistic

$\mathrm{t}=\mathrm{r} \quad\left\{(\mathrm{n}-2) / 1-\mathrm{r}^{2}\right\}=0.975 \quad\left\{(5-2) / 1-0.975^{2}\right\}=7.59$

Calculated value of ' $t$ ' is 0.125 and the tabulated value of ' $t$ ' with $(n-2=3) d$. $f$. is 2.353

As Cal. value $<$ Tab. Value, $\mathrm{H}_{0}$ is rejected and $\mathrm{H}_{1}$ is accepted.

Therefore it can be said that the variables, past performance and Brand image, are closely associated in case of Mutual funds.

13.3.1 Distribution of Investors choice between Open- and Close-ended Funds

While carrying out the current study, a sample-respondent of 20 mutual fund investors, from the various categories, were asked about their preference between open-ended and close-ended schemes in order to evaluate the popularity of these two. $63 \%$ of the investors like to invest in open-ended MF schemes, whereas only $36 \%$ prefer Close-ended ones.

\subsection{Demographic Variable-wise Analysis}

This analysis involves segmenting the respondents according to their income, education and the occupation. It is done to find out the level of investment in Mutual Funds and Life Insurance Policies.

13.4.1 Income: The annual income of the respondents was taken as one of the variables for classification. The income group of Rs. 1-2.5 lakhs invests a lot, whereas the investors in the income group of Rs.7.5 lakhs and above invest a little.

13.4.2 Profession: The preference-analysis of respondents according to their profession indicates greater differences in certain segments. Government and the private sector employees don't have the same idea towards every investment category. When LIC is more preferred mode of investment among the Government servants, the MFs is more favored amongst the private sector employees.

13.4.3 Educational Qualification: To analyze the investors' preferences over their educational level, the data under four 
scale levels - under graduate, graduate, postgraduate and the professional degree - had been collected. It is observed that the graduate $\&$ postgraduate investors are investing more in life insurance and the professional people are investing more in mutual funds.

\subsection{Major sources of the information for Investors}

There are many sources from which investors get the information regarding availability of various investment avenues. The most popular among them is found to be the newspaper (40\%). $32 \%$ of the investors identify agents, $15 \%$ identify friends, $7 \%$ identify distribution houses as their main source of information, whereas only $6 \%$ get information directly from the company.

\begin{tabular}{|l|c|}
\hline Sources of Information & Percentage of the Investors \\
\hline Agents & 32 \\
\hline Direct from company & 6 \\
\hline Distribution House & 7 \\
\hline Friends & 15 \\
\hline Newspaper and Magazines. & 40 \\
\hline
\end{tabular}

\section{Conclusion and Findings}

Under the study, the researchers have tried to sketch the behavioral pattern of retail investors towards two important investment opportunities, i. e., mutual fund and life insurance. A couple of hypothesis in this regard have been selected and tested to reach to conclusions. And the research concludes with some important findings that will be valuable for both the investors and the companies having such investment opportunities.

(1) It is found that, the different investment pattern do not provide the same level of services with respect to age of the retail investors in India.

(2) Although the investment patterns provide more or less the same service, there exist differences depending on the education level of the investors. It is observed that investors with the graduate \& postgraduate level of academic qualification are investing more in life insurance and the professionals are investing more in mutual fund.

(3) The investors have a wide difference with respect to their profession and also the different investment patterns vary widely.

(4) It is found that on an average; the government servants are investing to the maximum extent $(7.16 \%)$, where as the students and other professional groups are investing the least $(0.6 \%)$.

(5) Male investors are more as compared to females in Indian retail market.

(6) It is clear that majority of the people (35\%) are investing with the objective of capital growth, followed by Tax saving $(28 \%)$ and only $17 \%$ are investing for the Retirement plan.

(7) Maximum investors (30\%) like to invest in life insurance followed by mutual fund $(20 \%) \&$ Government saving schemes (18\%).

(8) Majority of the respondents (58\%) belongs to the income group of 2.5-5 lakhs, followed by 5-7.5 lakhs income group.

(9) $75 \%$ of the investors in the income group of $2.5-5$ lakhs prefer to invest in the life insurance.

(10) $52 \%$ of the investors ranked LIC as number one, $33 \%$ ranked ICICI as number two and $15 \%$ ranked HDFC as number three in Indian insurance industry.

(11) Majority (68\%) of the investors is of view that the public sector insurance is better than the private sector.

(12) The brand image and the past performance of the Mutual funds are highly positively correlated (0.975).

(13) The variables, past performance and Brand image of the Mutual funds are more closely associated.

(14) $63 \%$ of the investors like to invest in open-ended Mutual fund schemes, whereas only $36 \%$ prefer Closed-ended ones.

(15) Investors who lie within the income group of Rs.1-2.5 lakhs invest a lot, whereas the investors in the income group of Rs.7.5 lakhs and above invest a little either in mutual fund or in life insurance.

(16) The Government servants invest more in life insurance and the private sector employees in Mutual funds. 
(18) $40 \%$ of the investors are in view that Newspaper and magazines is the main source of information, whereas only $6 \%$ get information directly from company.

\section{References}

Alinvi, F. \& Babri, M. (2007). Customers' Preferences of Insurance Services. Bachelor Thesis, International Business Program.

Barber, B. M. and Odean, T. (2004). Are Individual Investors Tax Savvy? Evidence from Retail and Discount Brokerage Accounts. Journal of Public Economics, 88 (1-2), 419-442.

Black, K. and Skipper, H. D. (2000). Life and Health Insurance. Upper Saddle River, NJ: Prentice-Hall.

Brown, S. J., W. N. Goetzmann, T. Hiraki, N. Shirishi, and M. Watanabe. (2003). Investor Sentiment in Japanese and US Daily Mutual Fund Flows. NBER.

Black. B. (2004). Are Retail Investors Better Off Today? Brooklyn Journal of Corporate, Financial \& Commercial Law (Forthcoming), Cincinnati Public Law Research Paper No. 07-34, available at SSRN: http://ssrn.com/abstract=1085744.Bottom of Form

Chakrabarti, A. and Rungta, H. (2000). Mutual Funds Industry in India: An indepth look into the problems of credibility, Risk and Brand. The ICFAI Journal of Applied Finance, 6 (2), 27-45.

Das, S. R., Martinez-Jerez, F. de A. and Tufano, P. (2005). eInformation: A Clinical Study of Investor Discussion and Sentiment . Financial Management, 34 (3), 103-137.

Enz, R. (2000). The S-Curve Relation Between Per Capital Income and Insurance Penetration. The Geneva Papers on Risk and Insurance - Issues and Practice, 25 (3), 396 - 406.

Fama, E. F. (1970). Efficient Capital Markets: A Review of Theory and Empirical Work. The Journal of Finance, 25 (2), 383-417.

Goetzman, W. N. and Peles, N. (1997). Cognitive Dissonance and Mutual Fund Investors. The Journal of Financial Research, 20 (2), 145-158.

Gupta, L. C. (1994). Mutual Funds and Asset Preference. Delhi: Society for Capital Market Research and Development.

Hartman, J., Shim, B. S., Barber, B. and O'Brien, M. (2006). Adolescents' Utilitarian and Hedonic Web Consumption Behavior: Hierarchical Influence of Personal Values and Innovativeness. Psychology \& Marketing, 23 (10), 813-839.

Ippolito, R. (1992). Consumer reaction to measures of poor quality: Evidence from Mutual Funds. Journal of Law and Economics, 35, 45-70.

Jambodekar, M. V. (1996). Marketing Strategies of Mutual Funds - Current Practices and Future Directions, Working Paper, UTI-IIMB Centre for Capital Markets Education and Research, Bangalore.

Kahneman, D., Knetsch, J. L. and Thaler, R. H. (1991). The Endowment Effect, Loss Aversion, and Status Quo Bias: Anomalies. Journal of Economic Perspectives, 5 (1), 193-206.

Khorana, A. and Servaes, H. (1999). Retail Investor Sentiment and Return Co movements. Journal of Finance, 61, 2451-2486.

Kulshreshta, C. M. (1994). Mastering Mutual Funds. New Delhi: Vision Books.

Lee, C. M. C., Shleifer, A. and Thaler, R. H. (1991). Investor Sentiment and the Closed-End Fund Puzzle. Journal of Finance, 46 (1), 75-109.

Lindley, D. (2007). Imperfect Information for consumers. Consumer Policy Review, 17, 74-79.

Lynch, A. W. and Musto, D. K. (2003). How investors interpret past fund returns? Journal of Finance, 58 (5), 2033-2058.

Odean, T. (1999). Do Investors Trade Too Much, American Economic Review, 89 (5), 1279-1298.

Omar, O. E. and Owusu-Frimpong, N. (2007). Using the theory of reasoned action to evaluate consumer attitudes and purchase intention towards life insurance in Nigeria. The Service Industries Journal, 27 (7), 1-14.

Keli, P. (2005). A Theory of Cognitive Dissonance. Stanford: Stanford University Press.

Rajarajan, V. (1998). Stages in Life Cycle and Investment Pattern. The Indian Journal of Commerce, 51 (2 \& 3), 27-36.

Rajeswari, T. R. and Moorthy, V. E. R. (2005). An Empirical Study on Factors Influencing the Mutual Fund/ Scheme Selection by Retail Investors. Indian Capital Markets - Trends and Dimensions (ed). New Delhi: Tata McGraw-Hill. 
Sen, S. and Madheswaran, S. (2007). Are Life Insurance Demand Determinants Valid for Selected Asian Economics and India? Paper for Presentation at the $11^{\text {th }}$ Annual Meeting of APRIA, NCCU Taipei, July 22-25 2007, 3.

Shankar, V. (1996). Retailing Mutual Funds: A consumer product model. The Hindu, 24 July, 26.

Shanmugham, R. (2000). Factors Influencing Investment Decisions. Indian Capital Markets - Trends and Dimensions (ed). New Delhi: Tata McGraw-Hill Publishing Company Limited.

Sikidar, S. and Singh, A. P. (1996). Financial Services: Investment in Equity and Mutual Funds - A Behavioral Study. In B. S. Bhatia and G. S. Batra, (eds). Management of Financial Services, New Delhi: Deep and Deep Publications, 136-145.

Sundar, S. P. V. (1998). Growth Prospects of Mutual Funds and Investor perception with special reference to Kothari Pioneer Mutual Fund. Project Report, Sri Srinivas Vidya Parishad, Andhra University, Visakhapatnam.

Tripathy, N. P. (1996). Mutual Fund in India: A Financial Service in Capital Market. Finance India, 10 (1), 85-91.

Warther, V. A. (1995). Aggregate Mutual Fund Flows and Security Returns. Journal of Financial Economics, 39, 209-235.

Whaley, R. E. (2000). The Investor Fear Gauge. Journal of Portfolio Management, 26 (3).

Zhang, S. and Dhar, R. (2000). Constructing Preferences: The Role of Comparisons in Consumers Judgment and Choice, Advances in Consumer Research, 27 (1), 101-110.

Zheng, L. (1999). Is money smart? A study of mutual fund investors' fund selection ability. Journal of Finance, 54, 901-933.

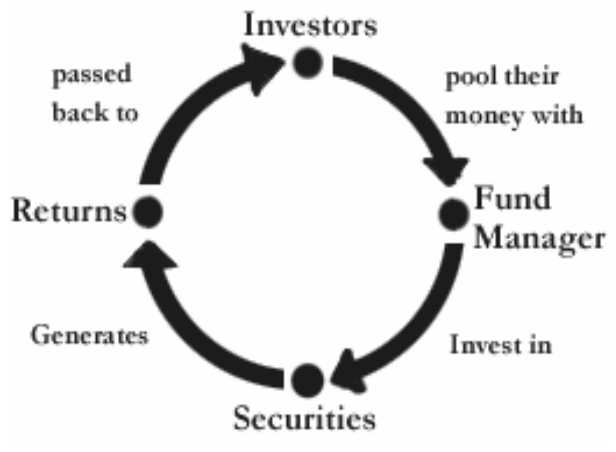

Figure 1. Working of a Mutual Fund

Table 1. Volume of Savings in India in Crore Rupees (at current prices)

\begin{tabular}{|l|r|r|r|r|r|r|}
\hline \multirow{2}{*}{ Sector } & \multicolumn{2}{|c|}{$1980-81$} & \multicolumn{2}{c|}{$1990-91$} & \multicolumn{2}{|c|}{$1998-99$} \\
\cline { 2 - 7 } & Value & Percent & Value & Percent & Value & Percent \\
\hline Household Savings & 21848 & 75.8 & 109623 & 84.4 & 325456 & 82.7 \\
\hline Private Savings & 2284 & 8.0 & 14940 & 11.5 & 67573 & 17.2 \\
\hline Public Savings & 4654 & 16.2 & 5436 & 4.1 & 5720 & 0.1 \\
\hline Total & 28786 & 100 & 129999 & 100 & 393601 & 100 \\
\hline
\end{tabular}


Table 2. Projection of life insurance and non-life insurance premiums, 2004-2014

\begin{tabular}{|c|c|c|c|c|}
\hline \multirow{2}{*}{ Years } & \multicolumn{2}{|c|}{ Life Insurance } & \multicolumn{2}{c|}{ Non-life Insurance } \\
\cline { 2 - 5 } & INR m & $\begin{array}{c}\text { INR m, constant } \\
2004 \text { prices }\end{array}$ & INR m & $\begin{array}{c}\text { INR m, constant } \\
2004 \text { prices }\end{array}$ \\
\hline 2004 & 749971 & 749971 & 203856 & 203856 \\
\hline 2005 & 871672 & 834136 & 234323 & 224233 \\
\hline 2006 & 1025957 & 934358 & 271830 & 247561 \\
\hline 2007 & 1201425 & 1042105 & 315522 & 273680 \\
\hline 2008 & 1403362 & 1159284 & 368094 & 304074 \\
\hline 2009 & 1667814 & 1312134 & 429750 & 338101 \\
\hline 2010 & 1983051 & 1485832 & 496953 & 372350 \\
\hline 2011 & 2366576 & 1688756 & 572727 & 408690 \\
\hline 2012 & 2804561 & 1905996 & 651736 & 442924 \\
\hline 2013 & 3326543 & 2153072 & 734778 & 475578 \\
\hline 2014 & 3947899 & 2433546 & 828433 & 510659 \\
\hline $\begin{array}{l}\text { Average growth rate } \\
\text { between 2004-2014 }\end{array}$ & $18.1 \%$ & $12.5 \%$ & $15.1 \%$ & $9.6 \%$ \\
\hline
\end{tabular}

Source: Swiss Re Economic Research \& Consulting 